\title{
EUGENIA, NEOGENIA E BIOÉTICA: Aproximações e Distanciamentos sob uma Perpectiva Jurídica de Reconhecimento de Direitos
}

\section{Dirceu Pereira Siqueira}

Pós-doutor em Direito pela Faculdade de Direito da Universidade de Coimbra (Portugal). Doutor e mestre em Direito Constitucional pela Instituição Toledo de Ensino - ITE/Bauru. Especialista Lato Sensu em Direito Civil e Processual Civil pelo Centro Universitário de Rio Preto. Pesquisador bolsista - modalidade Produtividade em Pesquisa para Doutor (PPD) do Instituto Cesumar de Ciência, Tecnologia e Inovação (Iceti). Coordenador e professor permanente do Programa de Mestrado em Direito do Centro Universitário Cesumar (UniCesumar) e nos cursos de Graduação em Direito da Universidade de Araraquara (Uniara), do Centro Universitário Unifafibe (Unifafibe) e do Centro Universitário da Fundação Educacional de Barretos (Unifeb). Professor-convidado do Programa de Mestrado em "Gestão Estratégica de Empresas - Master Of Science in Administrative Studies (MSAS)" - Disciplina "Ética e Legislação" University Missouri State - EUA. Consultor jurídico. Parecerista. Advogado. dpsiqueira@uol.com.br

\section{Letícia Mársico Curti}

Mestranda em Direito na área de Direitos da Personalidade pela Universidade Unicesumar. Especialista em Gestão Pública pela Faculdade Eficaz (2017). Graduada em Direito pela Universidade Estadual de Maringá (2016). Atualmente é advogada liberal da Ordem dos Advogados do Paraná (PR). leticurti@icloud.com

\section{Resumo:}

0 trabalho em pauta tem por objetivo trazer uma melhor explicação a respeito dos conceitos de eugenia, que teve seu desenvolvimento levado a efeito por um estudioso inglês chamado Francis Galton; e a respeito da neogenia, termo que caracteriza as práticas eugênicas em associação com o avanço da Engenharia Genética, que tem se focado no objetivo de mapear o genoma humano, para que se façam alterações por meio de uma seleção pré-implantatória dos gametas. Realiza-se também a explanação das diferenças entre a prática da eugenia positiva, que se resume na seleção de caracteres físicos, como a cor dos olhos, da pele, entre outros, e a eugenia negativa, que é caracterizada pela seleção dos gametas para supressão de doenças congênitas, possibilitando a detecção destas mesmo antes do nascimento, e então as eliminando. Posteriormente apresenta-se uma situação histórico-evolutiva, que mostra o progresso da eugenia, desde a realização dos "tribunais biológicos" nos Estados Unidos da América, em que os juízes sentenciavam a atitude a ser tomada para com aqueles conside- 
rados inferiores social e biologicamente, até a prática dos princípios eugênicos pelo governo nazista, na metade do século 20 (época do conhecido "Holocausto", promovendo a morte de mais de 6 milhões de judeus, além de outras classes que não se encaixavam nos critérios da "raça superior" dos nazistas - a raça ariana). Ademais, aborda-se o prisma sociológico e religioso do tema, verificando em que divergem e em que se assemelham, além de propiciar explicações gerais acerca do aborto eugênico. Finalmente, faz-se uma análise axiológica dos aspectos médico-legais, englobando a bioética, que envolve a responsabilidade médica.

Palavras-chave:

Neogenia. Biotecnologia. Eugenia. Bioética.

\section{EUGENIC, NEOGENIC AND BIOETHICS: APPROACHES AND DISTANCES UNDER A LEGAL PERSPECTIVE OF RECOGNITION OF RIGHTS}

\section{Abstract:}

The scope of this work is to better explain the concepts of eugenics, which was developed by a British scholar named Francis Galton, and neogenics, a concept adopted to designate the eugenic practices associated with the advancement of genetic engineering, which is working to map the human genome, in order to make changes through a selection that is made before the implant of the gametes. There is also the distinction between so-called positive eugenics, which is nothing more than the selection of physical traits, like skin color, eyes, among others, and negative eugenics, which is the technique of selection of gametes for elimination of congenital diseases, making it possible to detect these diseases even before birth, eliminating it. After this, there is a historical context, which shows the evolution of eugenics, including the holding of "biological courts" in the United States of America, where the judges decided what action to take to those considered socially and biologically inferior to the practice of the eugenics' doctrine by the Nazi government in the mid-twentieth century, the period known as "Holocaust" that resulted in the deaths of more than six million Jews, among other classes that did not fit the standards of "race top" of the Nazis, who considered it to be, the Aryan race. Furthermore, are addressed the religious and sociological point of the question, checking in what they agree and in what they disagree, also drawing general explanations about eugenic abortion. Finally, we analyze the medicine-legal, bioethics encompassing, involving medical responsibility.

\section{Keywords:}

Neogenic. Biotechnology. Eugenic. Bioethics.

Recebido em: 4/4/2018

Aceito em: 4/6/2018

\section{Sumário:}

1 Introdução. 2 Dos Aspectos Gerais da Eugenia. 2.1 Conceito de Eugenia e Neogenia. 2.2 Eugenia Positiva e Negativa. 2.3 Evolução Histórica. 3 Dos Aspectos Controvertidos da Prática da Neogenia. 3.1 Aspecto Religioso Cristão. 3.2 Aspecto Sociológico. 3.3 Aborto Eugênico. 4 Aspectos Médico-Legais. 4.1 Legislação Vigente no Brasil. 4.2 Deficiência do Processo Legislativo. 4.3 Bioética. 5 Conclusão. 6 Referências. 


\section{INTRODUÇÃO}

O objetivo estabelecido inicialmente é de se fixar um paralelo acerca do tema, de modo a propiciar uma visão sistêmica da matéria abordada, expondo a necessidade de explorar os aspectos gerais da eugenia. Após a análise segue em três vertentes, sendo elas: a primeira dos "conceitos de eugenia e neogenia", em que há a pretensão de abordar de maneira genérica e contemporânea o termo eugenia, demonstrando quais são os fins almejados com o uso de suas práticas, além da explanação de como ocorreu esta evolução até que se chegasse ao que se conhece hoje como neogenia (seleção pré-implantatória de gametas). O segundo item traz as diferenças conceituais e práticas do que se ocasionou nominar de "eugenia positiva" e "eugenia negativa", fazendo a demonstraçáo da linha tênue que as separa, pois, enquanto a primeira objetiva que as características biológicas sejam selecionadas, características estas como cor dos olhos e altura; a outra traz por escopo a eliminação de possíveis doenças congênitas. Neste momento (terceiro item) perpassa-se pela evolução histórica das práticas eugênicas, mostrando que tais ideias já eram espalhadas e levadas adiante, como ocorreu em Esparta, mesmo antes de que tal terminologia fosse criada. Consta também que já eram mencionadas em obras de grande relevo literário, a exemplo da clássica obra $A$ república, de Platáo. Posteriormente à criaçáo do conceito propriamente dito e melhora da moldagem de sua doutrina, os Estados Unidos adotaram tais práticas, bem como a Alemanha nazista, o que culminou em um dos massacres históricos mais estrondosos.

Já na segunda parte, quando a abordagem concentra-se nos aspectos controvertidos da eugenia, primeiramente traz-se à tona o lado religioso cristão, comparando os preceitos bíblicos, nos quais os adeptos professos desta fé pautam-se para tratar da questáo, à aplicação da prática, apresentando o resultado destes pensamentos. De um prisma mais científico, adentra-se na abordagem do aspecto sociológico, o qual abrange os problemas que a limitaçáo do uso das práticas eugênicas pode causar, usando o exemplo de uma possível instabilidade social gerada por uma espécie de discriminação genética. Ao final do item, após explorar os aspectos sociológicos e religiosos, apresenta-se uma análise a respeito do chamado "aborto eugênico", que tem dado causa a intensos debates no mundo da ciência, e que já vem sendo permitido em alguns casos no Brasil mediante algumas decisóes judiciais neste sentido. Um dos casos em que é permitido o aborto eugênico é 
quando ocorre uma malformação fetal, por exemplo, em situações de fetos sem cérebro. Ainda em 2012, o Supremo Tribunal Federal - STF - decidiu a favor da descriminalização do aborto de anencéfalos, liberando, portanto, a interrupção da gravidez nesses casos. Segundo o ministro Luiz Fux, do STF, "impedir a interrupção da gravidez sob ameaça penal equivale à tortura”. Por outro lado, diz Cezar Peluso, que "no caso do extermínio do anencéfalo, encena-se a atuação avassaladora do ser poderoso superior que, detentor de toda força, infringe a pena de morte a um incapaz de prescindir à agressão e de esboçar-lhe qualquer defesa”, caracterizando, entâo, uma prática eugenista de seleção. Paira a dúvida: alguém tem esse direito?

Por fim, o tema "aspectos médico-legais" ganha fôlego de modo que ocorre uma análise sobre a legislação do Biodireito, vigente no país, especialmente a que trata da eugenia, que é de muita escassez. À exceção de algumas resoluções do Conselho Federal de Medicina, que não são exatamente uma legislação, e sim um dispositivo norteador para as profissóes da área, não se encontram dispositivos outros que tratem do assunto no Estado. Este item também é subdividido em três itens, o primeiro chamado "legislação vigente no país", o segundo "deficiência do processo legislativo", que demonstra alguns dos fatores que fazem com que haja tantas mazelas na legislação sobre este tema, e o terceiro momento, que aborda a bioética, o qual destaca a importância de se estudá-la e a disseminar no país, e faz com que sempre se tomem as posiçóes mais ponderadas, o que proporciona uma harmonização entre a ética e os avanços da biotecnologia.

\section{DOS ASPECTOS GERAIS DA EUGENIA}

\subsection{Conceito de Eugenia e Neogenia}

O termo "eugenia", foi desenvolvido no ano de 1883 por Francis Galton (1822-1911), um importante antropólogo, meteorologista, matemático e estatístico inglês e significa "bem-nascido". Primo de Charles Darwin, e baseado em suas ideias, criou o conceito de eugenia e pregava a necessidade de se impedir a procriaçáo dos humanos "inferiores" biológica e sociologicamente. Em área de diâmetro oposto, defendia que os casamentos e procriação entre seres humanos considerados superio- 
res deveriam ser incentivados. Galton também foi um dos responsáveis por desenvolver testes de inteligência, no intuito de selecionar homens e mulheres brilhantes que seriam destinados à reprodução seletiva. Deu ainda à "eugenia" a definição como sendo o estudo dos agentes sob o controle social que podem melhorar ou empobrecer as qualidades raciais das futuras geraçôes, sejam físicas ou mentais. Em outras palavras, melhoramento genético. Entendia entáo, que estes "cruzamentos indesejados" deviam ser evitados, e assim a raça humana poderia ser aperfeiçoada.

Como se percebe, estas ideias tiveram início na Inglaterra, e foram levadas para os Estados Unidos da América, onde a disseminação da prática da eugenia aconteceu no início do século 20, fazendo com que cientistas, com a desculpa da higienização, cometessem diversas atrocidades, objetivando um melhoramento genético da população, simplesmente desconsiderando tudo o que hoje se entende por dignidade da pessoa humana. Faziam a análise de vários fatores biológicos e sociais dos indivíduos do país, e, dessa forma, baseados na doutrina eugênica, selecionavam aqueles que deveriam ser impedidos de passarem suas condiçóes genéticas para uma próxima geração, levando-os ao que chamavam de "tribunal biológico", em que um juiz, com base em laudos e estudos médicos, decidiria que prática deveria ser adotada. Realizavam atos como a esterilização forçada nos indivíduos definidos como inferiores, os quais eram chamados de "vermes", "mestiços" e "subumanos", além da prisão dos considerados inadequados aos padróes daquela elite pautada na cruel doutrina eugênica.

Um tempo depois foram utilizadas essas mesmas práticas no governo nazista, para a limitação da humanidade a uma "raça pura", a raça ariana, a qual, segundo os planos de Hitler, seria aquela que reconstruiria toda a Alemanha.

Com o fim da Segunda Guerra Mundial e deposição do governo nazista, adormeceu, aparentemente, o pensamento eugênico. Nas seguintes décadas, entretanto, o processo de aperfeiçoamento acelerado ao qual a ciência foi submetida, de uma forma nunca vista anteriormente, fez com que surgissem novas ciências, a exemplo da Engenharia Genética, que foi responsável por desenvolver técnicas de manipulação genética em seres humanos, e proporcionou o terreno necessário para que revivessem no coraçáo dos sedentos por uma raça superior aquelas ideias até então apagadas. 
Somente apontar as mazelas causadas pela ideia da eugenia não é certo, uma vez que avanços extraordinários no mapeamento do genoma humano possibilitaram a detecção e tratamento de doenças as mais diversas, até entấo sem solução, por meio do desenvolvimento do procedimento eugênico. Houve desenvolvimento, sim, mas, ao mesmo tempo, abriu-se precedentes para que se gerasse uma discriminação genética, assim como ocorreu nos Estados Unidos e em alguns países europeus. Por essa razão, faz-se necessária muita cautela no que diz respeito ao tema em questão. Dessa forma, cabe aos países e comissóes científicas se reunirem para um debate acerca do assunto, analisarem o que há de benéfico na prática e quais seriam os limites para o seu uso, pois do contrário pode-se gerar uma catastrófica instabilidade social, o que faria com que os detentores de melhores condições genéticas obtivessem prioridade no mercado de trabalho, e até mesmo em competiçóes esportivas, fazendo com que o esforço e dedicação do atleta ficassem em segundo plano, pois o predominante seriam suas características genéticas.

É justamente neste aspecto de melhoramentos genéticos feitos em laboratório mediante o mapeamento do genoma humano, que se pode falar na chamada "neogenia”, que seria uma evolução das práticas adotadas no passado, utilizando-se do conhecimento científico para seu desenvolvimento, como nos ensinam José Sebastião de Oliveira e Denise Hammerschmidt:

Não obstante, com a aparição da biotecnologia da engenharia genética e, em particular, com as técnicas de reprodução humana assistida, surge a necessidade de reformular o conceito "clássico" de eugenia e reapresentá-lo em outros termos. É o que se conhece como neo-eugenia. É preciso salientar nesse ponto que a neo-eugenia tem à sua disposição estes poderosos meios da biotecnologia da engenharia genética, os quais proporcionam um conhecimento cada vez mais amplo e preciso sobre o genoma humano da espécie dos indivíduos (2008, p. 176-190).

Assim, é necessário que o mundo científico esteja embasado pelos padróes da ética, para que não se venha a ferir a dignidade da pessoa humana e reacender ideias cruéis e elitistas, sob a justificativa de melhoramento nas técnicas de reprodução assistida. E dependendo da evolução da prática, é necessário que a ordem pública intervenha para fiscalizar a maneira como ela está sendo adotada, e se não vai gerar, como referido anteriormente, um preconceito genético, que consequen- 
temente resultaria em uma instabilidade social, mesmo que para tanto necessite utilizar métodos coercitivos. Por essa razão, deve-se adotar um raciocínio moral nas tomadas de decisão em relação a questôes sociocientíficas. Nesse sentido, argumentam Márcio Andre Guimarães, Washington Luiz Pacheco de Carvalho e Mônica Santos Oliveira:

O raciocínio moral é um tipo de raciocínio informal que é levado em conta na resoluçáo de dilemas sociocientíficos. Seria um erro pensar que somente a informação científica é utilizada para a tomada de decisões e a emissão de julgamentos. Portanto o conhecimento biológico, como no caso da genética, deve subsidiar, mas não é o fator determinante nas tomadas de decisões. Pesquisas recentes sobre a influência do conhecimento do conteúdo no raciocínio informal mostram resultados divergentes, desde nenhuma participação do conhecimento científico até um importante papel deste na elaboração de raciocínio moral (2010, p. 465-477).

Logo, é de suma importância que o raciocínio moral seja considerado pelas autoridades governamentais, e principalmente pelos cientistas que têm contribuído de forma significativa para os avanços na área da Engenharia Genética, enquadrada no campo da biotecnologia, ao se decidir sobre o futuro das intervençóes humanas feitas em laboratórios na seleção pré-implantatória de gametas, que mais especificamente pode ser chamada de neogenia, ponderando acerca da distinção das práticas eugênicas, que podem ser subdivididas em eugenia positiva e eugenia negativa, devido a uma tênue diferença entre ambas, que leva à caracterização desta divisão, e que serão analisadas no próximo tópico.

\subsection{Eugenia Positiva e Negativa}

Pode-se classificar os processos eugênicos de dois modos, ou seja, a chamada “eugenia positiva” e a "eugenia negativa”. De início faz-se necessário entender o que é uma ação eugênica em seu sentido estrito, como observam Lilian Denise Mai e Emília Luigia Saporiti Angerami: 
A partir do momento em que a eugenia é entendida como sendo a preocupação com a saúde e constituiçáo das futuras geraçóes, toda e qualquer utilização de meios e conhecimentos científicos em prol do nascimento de uma criança física e mentalmente saudável pode ser considerada uma ação eugênica (2006, p. 251-258).

Assim sendo, toda intervenção, tanto no intuito de estimular o casamento entre pessoas com características genéticas superiores (no padrão da sociedade inserida), quanto no de promover intervençóes laboratoriais com o uso da crescente evolução científica da biotecnologia, pode ser considerada uma ação eugênica. Determinado tipo de intervenção, todavia, tem por objetivo a eliminação de características indesejáveis, enquanto outro visa a acrescentar características que sejam desejadas, consideradas como ideal genético na sociedade. E é justamente neste ponto que se encontram divergências e torna-se possível fazer diferenciação entre determinados tipos de açóes eugênicas e outros.

Eugenia negativa é aquela praticada segundo a doutrina eugênica com o intuito de eliminar características indesejadas, a exemplo do que se fazia nos Estados Unidos da América e na Alemanha, quando se proibia pessoas classificadas como geneticamente inferiores de se reproduzirem com indivíduos considerados geneticamente superiores, e até mesmo as esterilizando, para que não repassassem suas características genéticas para as geraçóes futuras, utilizando-se do conhecimento de Darwin, que defende em $A$ origem das espécies o processo de seleção natural, o qual consiste em afirmar que as características favoráveis, as quais são hereditárias, tornam-se mais comuns em geraçóes sucessivas de uma população de organismos que se reproduzem, e que características desfavoráveis que são hereditárias tornam-se menos comuns. A seleção natural age no fenótipo, ou nas características observáveis de um organismo, de tal forma que indivíduos com fenótipos favoráveis têm mais chances de sobreviver e se reproduzir do que aqueles com fenótipos menos favoráveis. Se esses fenótipos apresentam uma base genética, então o genótipo associado com o fenótipo favorável terá sua frequência aumentada na geração seguinte. Com o passar do tempo esse processo pode resultar em adaptaçóes que especializarão organismos em nichos ecológicos particulares e pode resultar na emergência de novas espécies. 
A seleção natural não distingue entre seleção ecológica e seleção sexual, na medida em que ela se refere às características - por exemplo, destreza de movimento - nas quais ambas podem atuar simultaneamente. Se uma variaçáo específica torna o descendente que a manifesta mais apto à sobrevivência e à reprodução bem-sucedida, esse descendente e sua prole terão mais chances de sobreviver do que os descendentes sem essa variação. As características originais, bem como as variaçóes que são inadequadas dentro do ponto de vista da adaptaçáo, deverão desaparecer conforme os descendentes que as possuem sejam substituídos pelos parentes mais bem-sucedidos. Assim, determinadas características são preservadas devido à vantagem seletiva que conferem a seus portadores, permitindo que um indivíduo deixe mais descendentes que aqueles sem essas características. Eventualmente, por meio de várias interações desses processos, os organismos podem acabar desenvolvendo características adaptativas mais e mais complexas.

Há também outros tipos de eugenia que podem ser chamadas de "eugenia negativa", a exemplo do que ocorre na "neogenia", reforçando mais uma vez seu significado e diferenciando do sentido clássico de eugenia com os conhecimentos transmitidos por José Sebastião de Oliveira e Denise Hammerschmidt:

Nesse particular aspecto, cumpre destacar a diferença entre a neo-eugenia e os movimentos eugênicos de princípios do século XX, caracterizados por bárbaras práticas de esterilização de deficientes físicos ou mentais ou por políticas criminosas de eliminação de grupos étnicos (judeus ou ciganos) e de pessoas de determinadas orientaçôes sexuais (homossexuais) praticadas por alguns regimes políticos. Tais pessoas eram concebidas como um problema social e coletivo, cuja solução era promovida por cientistas, pensadores, juristas e políticos. A nova eugenia se apresenta como uma questáo médica, própria da esfera da relação médico-paciente e, por isso, como um assunto de saúde individual, de saúde dos próprios interessados, de um direito à saúde - a nascer saudável - em relação a seus progenitores e suas faculdades ou liberdades reprodutivas (2008, p. 176-190).

Assim, utilizando-se das técnicas que propiciam a "neogenia" é possível fazer a detecção de problemas em determinados gametas, realizando então uma seleção pré-implantatória dos gametas, o que resulta no implante somente daqueles saudáveis, com o intuito de se eliminar o risco de desenvolvimento de doenças congênitas, as quais são adquiridas antes do nascimento ou até mesmo no primeiro mês de vida. 
Em campo diametralmente oposto encontra-se a eugenia positiva, que se caracteriza pela tomada de atitudes com a finalidade de preservar as características genéticas consideradas predominantes em uma sociedade, como era o caso da Alemanha, que disseminou a ideia de raça superior, no caso a ariana, a qual era protagonizada pela imagem de um homem alto, loiro, de olhos azuis, com o cérebro alongado, representando maior capacidade biológica que resultava em maior desenvolvimento intelectual. Uma das açôes eugênicas que podem ser enquadradas nesta categoria seria o incentivo à procriação entre aqueles indivíduos que fossem caracterizados como biologicamente superiores. Incentivos que poderiam vir por vias econômicas ou até mesmo com privilégios sociais. Já no campo da neogenia, é possível fazer a "eutelegênese", que consiste em uma seleção germinal no banco de sêmen, além da manipulaçáo laboratorial dos gametas, para selecionar aqueles que possuam a formação biológica necessária para o desenvolvimento de características que agradem aos pais da futura criança. Técnicas deste tipo vêm sido muito utilizadas nos últimos anos, e cada vez mais são procuradas por aqueles que têm condiçôes financeiras para realizá-las, e desejam "personalizar" seus filhos da maneira que escolherem, fazendo uma espécie de seleção artificial, desafiando a natureza e seu jogo de probabilidades. Lembrando ainda que este tipo de técnica vem sendo utilizada para o que se denominou "eugenia às avessas", que consiste em selecionar características desfavoráveis, para que o filho nasça problemático. Pode parecer aparentemente absurdo, porém uma pesquisa realizada pelo Centro de Genética e Política Pública da Universidade John Hopkins, nos EUA, demonstrou em um estudo feito em 190 clínicas de reprodução assistida, que 3\% dos pais que buscam seu auxílio querem selecionar embrióes que contenham algum tipo de deficiência física. Este é o caso das lésbicas Candace McCullough e Sharon Duchesneaum, de Maryland, EUA, ambas portadoras de deficiência auditiva, que no ano de 2002 solicitaram um doador de esperma com gene de surdez, para terem um filho também surdo, e assim o fizeram, alegando ser a surdez não uma doença, mas uma identidade cultural.

A prática da eugenia é muito combatida, e criticada por muitos, que se pautam em determinados fatores sociais, sejam eles morais, éticos, sociológicos, profissionais ou religiosos. Em geral, a eugenia positiva é criticada com maior intensidade, como se pode perceber ao ler este trecho, presente em um site ao expressar o que é eugenia, afirmando que esta visão cientificista, exclusivamente materialista, em que 
o homem é apenas uma engrenagem de um mecanismo maior - a sociedade ou o Estado - pretende "melhorar" a raça humana até gerar o "super-homem". A eugenia nasceu na época em que a ciência triunfante revolucionava o mundo da técnica. No materialismo existia uma grande tentação de utilizar o homem como um material ou animal, que pode ser melhorado por meio de cruzamentos e uma seleção "científica". A sociedade deve tratar aqueles que considere vítimas de taras, "disgênicos", inferiores, inadaptados, maldesenvolvidos, como membros gangrenados e amputá-los por razóes de higiene social, sem levar em conta as proibiçôes de uma moral "burguesa" derivada da superstição “judeu-cristã”. A relação com o médico ou o biólogo se transforma, então, numa relação que envolve três partes: o Estado, o médico e o doente. ${ }^{1}$

Isso posto, é possível perceber que a questão envolve sérias questóes éticas e morais, seja do ponto de vista religioso ou sociológico, gerando grandes controvérsias ideológicas, que serão analisadas nos próximos itens deste trabalho.

\subsection{Evolução Histórica}

Analisando os escritos de Platão, já na Grécia antiga, em especial os presentes em $A$ República, é possível perceber características do que atualmente se conhece como eugenia, pois já se falava em processos seletivos para aperfeiçoamento da sociedade. Além disso, no Peloponeso, os espartanos tinham uma preocupaçáo obsessiva com o que se entendia ser a "qualidade" de sua raça. A preocupaçáo e a necessidade de se constituir um exército forte acabariam requerendo um material humano "de primeira linha”. Dessa maneira, mantinham um acompanhamento cuidadoso na gravidez de suas mulheres, que eram levadas para fazer exercícios que possibilitavam uma melhor gestação. A criança, ao nascer, era avaliada por uma comissão de anciãos que buscava observar se o recém-nascido apresentava saúde perfeita, caso contrário ocorreria a sua execução (infanticídio). Tal prática atroz pode ser designada entre as técnicas de eugenia negativa, e visavam à eliminação de características que poderiam levar o indivíduo a sucumbir no campo de batalha, atrapalhando todos os seus companheiros.

1 Disponível em: <http://www.trdd.org/eugbr_1p.htm>. Acesso em: 1º nov. 2012. 
Para se entender a evolução histórica da eugenia para a neogenia, e o porquê da preocupação científica atual com o uso indiscriminado da seleção pré-implantatória dos gametas, é necessário reportar-se ao nazismo, movimento que surgiu na Alemanha no início do século 20, e teve como seu líder o austríaco Adolf Hitler. O objetivo do nazismo era resgatar o nacionalismo alemão, que há muito estava abalado devido às derrotas na Primeira Guerra Mundial, mediante a expansão de seu império, além de resgatar os territórios perdidos naquela guerra e, por fim, totalmente relacionado às práticas eugênicas, queriam desenvolver o que chamavam de "raça pura", que segundo eles seria a ariana. Logo, no seu entendimento, apenas os alemães "mais fortes", "mais bem selecionados", deveriam sobreviver para a reconstrução da Alemanha.

É certo que ideias eugênicas já existiam, e eram defendidas por muitos cientistas, tendo seu berço na Inglaterra, que sofreu transformações que propiciaram as condiçóes necessárias para o florescimento destas ideias, a saber, a transformaçóes resultantes do fim da Revolução Industrial, pois se vivia uma instabilidade social, e a vida urbana beirava o caos, necessitando a disseminação de políticas de higiene pública para se evitar a proliferação de doenças e prejuízos econômicos, porém atingiram seu ápice na Alemanha nazista, que se utilizava da prática para a realização do sonho de alguns líderes e cientistas inescrupulosos, que seria a criação desta raça superior, a qual dominaria o mundo.

Influenciados pelas ideias de Darwin, de que a seleção natural influenciaria o processo de sobrevivência dos seres vivos, muitos cientistas estudaram tal prática e criaram um novo conceito, o qual se tornou um movimento denominado "darwinismo social". Este movimento tinha por objetivo disseminar a importância de se fazer um rígido controle demográfico nos seres humanos, pois, segundo eles, algumas características biológicas e sociais determinavam uma "superioridade", e estes seres superiores deveriam ser preservados, pois eram os mais aptos para dar continuidade à raça. Pensavam então, que, infelizmente, os fracos também sobreviviam e propagavam sua genética, cabendo então aos cientistas "frear" sua propagação, impedindo os indivíduos "fracos" de se casarem com os "superiores", resultando assim em uma evolução física e intelectual das raças superiores. 
Pautando nessas ideias, e desenvolvendo-as, cientistas alemães, apoiados pelo governo nazista, iniciaram então a criação de estratégias para exercer este controle e propiciar a disseminação das características que davam origem a esta "raça superior". Inspiraram-se nos efeitos causados pelo processo eugênico nos Estados Unidos da América, nos chamados "tribunais biológicos", nos quais era realizada a esterilização forçada nos indivíduos considerados inferiores, os quais eram chamados de "vermes", "mestiços" e "subumanos", além da detenção dos socialmente inadequados aos padróes desejados por aquela elite racista. Assim, o nazismo cometeu inúmeras atrocidades nessa reconstruçáo da Alemanha, que desejava ser formada apenas por esta raça superior, a ariana, chegando a tal ponto que muitos confundiam os termos eugenia e nazismo, pois ambos já praticamente se misturavam.

Entre as açóes praticadas por Hitler no Terceiro Reich estavam as de esterilização dos alemães que possuíam deficiências físicas e mentais, e do incentivo às pessoas saudáveis para gerarem um grande número de filhos, a exemplo do que se fazia com a criação de centros de reprodução humana do programa Lebensborn, projeto iniciado pelo líder nazista Heinrich Himmler com o intuito de preservar as crianças detentoras de genes pertencentes à raça ariana, e que muitas vezes, caso não tivessem sido cuidadas pelo governo, teriam sido abortadas, pois ocorreu uma grande onda de abortos na Alemanha nos anos de 1940, com dados que chegam a afirmar que eram realizados cerca de 600 mil abortos anualmente no país, o que não era interessante para o governo, pois este perdia soldados para o exército, fazendo com que em 20 anos as perdas chegassem a cerca de 18 a 20 regimentos militares, que dariam força ao aparato militar alemão, impulsionando-o rumo ao táo almejado expansionismo, que o faria modelo e senhor do mundo.

Com as práticas eugênicas, o racismo alemão foi ganhando status de cientificidade por meio desta doutrina que inspirava as autoridades e grupos intelectuais de todas as partes do mundo. Faziam séries de exames antropométricos, que nada mais eram do que procedimentos utilizados na Alemanha nazista para catalogar características físicas presentes na população, criando um verdadeiro "cadastro biológico", atropelando a dignidade daqueles considerados inadequados para os planos futuros do Terceiro Reich. 
Estes eram, de maneira geral, os procedimentos praticados na Alemanha durante o governo nazista, o que resultou em um grande abuso à dignidade, levando à criação da carta de declaração dos Direitos Humanos no pós-guerra.

\section{DOS ASPECTOS CONTROVERTIDOS DA PRÁTICA DA NEOGENIA}

\subsection{Aspecto Religioso Cristão}

Do ponto de vista religioso cristão, de maneira nenhuma se poderia fazer uma seleção pré-implantatória dos gametas, seja manifestada na forma de eugenia negativa, com o intuito de impedir que a criança nasça com doenças congênitas, seja com o objetivo de selecionar gametas para escolher características biológicas que poderiam tornar o indivíduo em questão geneticamente superior dentro dos parâmetros da sociedade em que esteja inserido, pois isto feriria diretamente preceitos bíblicos imutáveis, relacionados à fé de que Deus tudo conhece e tudo pode, e de que não cai uma folha de uma árvore sem que Ele permita, logo, qualquer posicionamento em contrário seria uma afronta à fé e a determinados trechos bíblicos, como se pode encontrar no livro de Eclesiastes: "Atenta para a obra de Deus: por que quem poderá endireitar o que ele fez torto?” (Eclesiastes, 7:13). Também no livro de Exxodo, em que se pode constatar que a maneira como cada um nasce é determinada por Deus, mesmo que haja alguma deficiência: "E disse-lhe o Senhor: Quem fez a boca do homem? Ou quem fez o mudo, ou o surdo, ou o que vê, ou o cego? Não sou eu, o Senhor?” (4:11), além de trechos protagonizados por Jesus, como é possível ler no livro de João: "E passando Jesus, viu um cego de nascença. E os seus discípulos lhe perguntaram, dizendo: Rabi, quem pecou, este ou seu pai para que nascesse cego? Jesus respondeu: Nem ele pecou nem seus pais, mas foi assim para que se manifestem nele as obras de Deus" (9:1-3).

Como se percebe ao ler os trechos bíblicos expostos anteriormente, qualquer religioso que expresse total fé na Bíblia não concordaria com qualquer prática no sentido de seleção artificial que possa romper com a interação da seleção natural, que, dentro de seus parâmetros, é controlada por Deus. Nesse sentido, quando as 
crenças religiosas estão em xeque em relação ao conhecimento e práticas científicas, observa-se o surgimento de um importante embate jurídico, onde dois direitos devem ser sopesados e, democraticamente, um deles deverá se sobressair.

Assim, nas democracias, em que a vontade da maioria deve prevalecer, e em que esta maioria é composta majoritariamente por religiosos cristãos, dificilmente se conseguiria aprovar legislação no sentido de liberar práticas da Engenharia Genética para a seleção de caracteres em humanos, a não ser que tais práticas fossem direitos constitucionalmente assegurados, como muitos defendem ser o direito a nascer saudável, evitando doenças congênitas, mediante práticas de neogenia, porém mesmo nestas condições, e já tendo feito os esclarecimentos necessários acerca do ponto de vista religioso cristão em relação às práticas neogênicas, é necessário também se discutir o ponto de vista sociológico, para que se possa estudar a possibilidade do surgimento de situaçôes indesejadas na sociedade no caso de liberação da prática. Este tema já foi superficialmente tratado neste trabalho anteriormente, e será aprofundado no próximo subitem, que tem por título "Aspecto Sociológico".

\title{
3.2 Aspecto Sociológico
}

Os avanços biotecnológicos têm causado um grande impacto na sociedade nos últimos anos, como nos esclarecem José Sebastiáo de Oliveira e Denise Hammerschmidt:

\begin{abstract}
A genômica é uma das inúmeras tecnologias que apareceram nas últimas décadas do século XX. Os impactos dessas tecnologias nas áreas das ciências biomédicas e de saúde são enormes. Nos últimos anos, os avanços da engenharia genética e da biotecnologia têm permitido transladar o conhecimento sobre a vida humana da incerteza e penumbra das elucubraçóes para a seguridade dos dados científicos. Os espetaculares avanços no conhecimento do genoma humano resultam em uma clara esperança para a deteç̧ão, prevenção e tratamento de numerosas enfermidades até agora sem solução (2008, p. 176-190).
\end{abstract}

Em um primeiro momento, ao se analisar os processos eugênicos desenvolvidos em laboratório, por intermédio da evoluçáo dos conhecimentos na Biotecnologia e Engenharia Genética, nomeados de "neogenia”, nada têm de preocupante se 
comparados aos atos eugênicos discriminatórios realizados no decorrer da História, porém um exame mais aprofundado leva a repensar esta questáo e quais seriam as consequências do uso ilimitado das práticas em longo prazo na sociedade. Isto é objeto de estudo da Sociologia, e é este aspecto sociológico que será analisado a partir de agora.

Todo este avanço tecnológico tem um lado que precisa ser cuidadosamente analisado, pois este progresso pode gerar uma insegurança em relação ao futuro e até mesmo uma instabilidade social, a partir do momento em que todos tenham acesso ao mapeamento genético de outros, analisando todas as suas características, podendo até mesmo gerar um velado preconceito genético na sociedade.

As práticas da neogenia associadas a este determinismo genético podem ser perigosas, entendendo determinismo genético como o postulado de que nossas características relacionadas ao nosso comportamento a à nossa personalidade estão irrefutavelmente ligadas ao gene. Desta forma, analisando-se o mapeamento genético de alguém se poderia concluir que "tipo" de pessoa ela é e quais qualidades ela teria aptidão para desenvolver, se representa algum perigo em determinado aspecto e seu modo de ser. Como se pode perceber, em uma sociedade pautada nestes moldes, o indivíduo que for formado por gametas previamente selecionados em laboratório teria maiores vantagens tanto na vida profissional quanto na vida social, estabelecendo-se assim uma espécie de padrão, que colocaria em risco todos os fatores do âmbito social como o conhecemos atualmente.

Esta discriminação genética poderia criar catástrofes irreversíveis, como segregaçáo daqueles que fossem considerados geneticamente inferiores. Logo, conclui-se que assim como o aspecto religioso, o aspecto sociológico entende que de maneira nenhuma a eugenia positiva deve ser permitida, pois assim se formaria um modelo para a sociedade de uma raça superior, como o ocorrido na Alemanha nazista em relação à raça ariana, com seu estereótipo de homem loiro, alto e de olhos azuis. E apesar de admitir as vantagens da eugenia negativa no combate às doenças congênitas, entende-se que no longo prazo mesmo tal prática seria perigosa, pois a informação por parte de terceiros da condição genética dos outros indivíduos da sociedade acabaria também por resultar em uma discriminação genética que deve ser combatida. Defende-se, entâo, que mesmo a prática da eugenia negativa 
só deve ser utilizada em casos extremos para a eliminação de algumas doenças em especial, e mesmo assim resguardando o direito de segredo da informação genética de todos os indivíduos.

Apesar de ser analisado por outro viés, o resultado do aspecto sociológico acaba não sendo tão diferente do aspecto religioso, com ambos entendendo a instabilidade que as práticas neogênicas gerariam, alterando a ordem natural das coisas.

\subsection{Aborto Eugênico}

Entre as questôes controvertidas relacionadas à prática da neogenia está a questão do ato conhecido como "aborto eugênico". Esta prática insere-se no contexto da eugenia negativa, e já é aceita em alguns países, a exemplo da França, que permite sua realização em qualquer período da gestação, caso se detecte que a criança possa vir a nascer com alguma doença grave que esteja no rol daquelas entendidas como incuráveis pela medicina dado o seu atual estágio de avanço, estando até mesmo normatizado no código de saúde pública francês, e de maneira astuciosa é por muitos chamado de aborto terapêutico, que só tem sua realização aceita em razão das características defeituosas do feto.

É evidente que nestes países se priorizou o bem-estar da mãe em relação à vida do feto, pois se fosse analisado de maneira diversa, jamais seriam aceitas tais argumentações, como preleciona Prado, Carvalho e Carvalho:

[...] Essa indicaçáo permite o aborto quando existem riscos fundados de que o embriáo ou o feto sejam portadores de graves anomalias genéticas de qualquer natureza ou de outros defeitos físicos ou psíquicos decorrentes da gravidez. Trata-se de causa de exclusão da culpabilidade, pela inexigibilidade de conduta diversa. Demais disso, argumenta-se que não se pode exigir que a mãe dedique sua própria vida a cuidar de alguém portador de graves anomalias. Confere-se, pois preponderância ao interesse materno de preservar a própria saúde ante a vida do nascituro, despojada das garantias mínimas de bem-estar [...] (2014, p. 663-681). 
No Brasil ainda não se tem dispositivo normativo que discorra acerca do aborto eugênico especificamente, destacando-se que a sua prática só não é punida pelo Código Penal quando seja a única maneira de salvar a vida da gestante ou quando a gravidez é consequência de um estupro, estes dois casos entendidos como justificáveis, como afirma Genival Veloso de França:

No primeiro caso, conhecido por aborto terapêutico, estaria justificado como forma desesperada de salvar-se a vida de uma mãe, cujo valor, nessas circunstâncias, seria mais relevante. Ainda assim, afirmamos que o ato só será licito se a gestante apresenta perigo vital, se esse perigo estiver sob dependência da gravidez, se a interrupção da gravidez fizer cessar aquele perigo e se esse for o único procedimento capaz de salvar-lhe a vida. No segundo caso, conhecido como aborto sentimental, moral ou piedoso, estará justificada a não punibilidade por não se admitir que uma mulher chegasse à maternidade pela violência e pela coaçáo, trazendo no seu ventre um filho indesejado e marcado para sempre pelo ultraje recebido (2001, p. 46-47).

Não obstante, em alguns casos no país o aborto eugênico já vem sendo aceito quando se trata de fetos anencefálicos, justificado pelo fato de não ter por escopo o melhoramento da raça ou coisas do gênero, mas sim evitar o sofrimento emocional da mãe que gerará um filho que nascerá cientificamente sem vida, desprovido de cérebro. Neste sentido ocorre o entendimento do STF.

É certo que ainda não há casos suficientes para que se possa falar em uma jurisprudência nacional, mas a tendência é que argumentos semelhantes comecem a ser utilizados por outros magistrados em todas as regióes do país, por ser pautada em argumentos científicos que ofereçam certa credibilidade quando se trata da detecção destes casos, com margem de erro considerada inexistente. Desta forma, talvez em pouco tempo se poderá falar em uma jurisprudência nacional acerca de tema táo controverso quanto o é o tema do aborto eugênico. 


\section{ASPECTOS MÉDICO-LEGAIS}

\subsection{Legislação Vigente no Brasil}

Não há como se discorrer sobre uma legislação vigente no país acerca da eugenia, e mais especificamente da neogenia, pois os dispositivos normativos são quase que inexistentes, não havendo nada concreto que possa dar um direcionamento aos magistrados na hora de decidirem acerca de questóes relacionadas às técnicas de manipulação e seleção pré-implantatória dos gametas.

Também na CF não há nada específico ao tema, e muito se criticou o atual Código Civil por não ter abordado os assuntos relacionados ao Biodireito, mas os componentes do grupo que o confeccionaram defendem-se afirmando que se trata de matéria demasiadamente controversa, carecendo de maiores avanços na doutrina nacional para que se possa tomar uma decisão que seja mais condizente com a realidade atual do país. Ademais, diz-se que os avanços tecnológicos possibilitam constantes mudanças nesta área, fazendo com que os dispositivos normativos não consigam acompanhá-la, estando sempre ultrapassados, logo, qualquer esforço neste sentido teria sido perdido em pouco tempo.

Como dito, realmente não há como se falar em dispositivos normativos. O que há são resoluções do Conselho Federal de Medicina (CFM), que não devem ser entendidas como leis, e sim como direcionamentos para os profissionais das áreas médicas, uma espécie de bússola, um dispositivo deontológico, ou seja, que traduz o "dever-ser", que norteie o trabalho de médicos, enfermeiros e clínicas em geral. Assim, há a resolução número 1.957/2010, que trata da reprodução assistida. Em geral a prática da reprodução assistida (RA) é buscada por aqueles que possuem problemas biológicos e não podem ter filhos naturalmente. $\mathrm{O}$ caput desta resolução traz as seguintes consideraçóes:

O CONSELHO FEDERAL DE MEDICINA, no uso das atribuiçóes conferidas pela Lei $\mathrm{n}^{\circ} 3.268$, de 30 de setembro de 1957, alterada pela Lei $\mathrm{n}^{\circ} 11.000$, de 15 de dezembro de 2004, regulamentada pelo Decreto no 44.045, de 19 de julho de 1958, e 
CONSIDERANDO a importância da infertilidade humana como um problema de saúde, com implicaçóes médicas e psicológicas, e a legitimidade do anseio de superá-la;

CONSIDERANDO que o avanço do conhecimento científico permite solucionar vários dos casos de reprodução humana;

CONSIDERANDO que as técnicas de reprodução assistida têm possibilitado a procriação em diversas circunstâncias, o que não era possível pelos procedimentos tradicionais;

CONSIDERANDO a necessidade de harmonizar o uso dessas técnicas com os princípios da ética médica;

CONSIDERANDO, finalmente, o decidido na sessão plenária do Conselho Federal de Medicina realizada em 15 de dezembro de $2010 .^{2}$

Em seguida traz seus artigos, mas como se pode perceber, o caput já apresenta algumas importantes considerações, tratando da importância da harmonização dos usos da prática de reprodução assistida com os princípios da ética média, que também pode ser chamada de "bioética" e será tratada neste momento.

Já no segundo artigo, nas disposiçōes gerais, é possível detectar resquícios de referência específica às práticas da neogenia:

1 - As técnicas de reprodução assistida (RA) têm o papel de auxiliar na resolução dos problemas de reprodução humana, facilitando o processo de procriação quando outras terapêuticas tenham se revelado ineficazes ou consideradas inapropriadas.

2 - As técnicas de RA podem ser utilizadas desde que exista probabilidade efetiva de sucesso e náo se incorra em risco grave de saúde para a paciente ou o possível descendente.

3 - O consentimento informado será obrigatório a todos os pacientes submetidos às técnicas de reprodução assistida, inclusive aos doadores. Os aspectos médicos envolvendo as circunstâncias da aplicação de uma técnica de RA serão detalhadamente expostos, assim como os resultados obtidos naquela unidade

2 Resolução CFM nº 1.957/2010. 
de tratamento com a técnica proposta. As informações devem também atingir dados de caráter biológico, jurídico, ético e econômico. $\mathrm{O}$ documento de consentimento informado será expresso em formulário especial e estará completo com a concordância, por escrito, das pessoas submetidas às técnicas de reprodução assistida.

4 - As técnicas de RA não devem ser aplicadas com a intenção de selecionar o sexo (sexagem) ou qualquer outra característica biológica do futuro filho, exceto quando se trate de evitar doenças ligadas ao sexo do filho que venha a nascer.

5-É proibida a fecundação de oócitos humanos com qualquer outra finalidade que não a procriação humana.

6 - O número máximo de oócitos e embrióes a serem transferidos para a receptora não pode ser superior a quatro. Em relação ao número de embrióes a serem transferidos, são feitas as seguintes determinaçóes: a) mulheres com até 35 anos: até dois embrióes); b) mulheres entre 36 e 39 anos: até três embrióes; c) mulheres com 40 anos ou mais: até quatro embrióes.

7 - Em caso de gravidez múltipla, decorrente do uso de técnicas de RA, é proibida a utilizaçáo de procedimentos que visem à redução embrionária. ${ }^{3}$

O item 4 remete diretamente às técnicas de seleção pré-implantatória dos gametas, referindo-se mais especificamente à sexagem, que não deve ser feita, uma vez que também geraria uma grande instabilidade social, pois é a técnica que possibilita a escolha do sexo da criança, tratando-se de seleçáo artificial que desregularia os processos naturais que fazem com que haja praticamente o mesmo número de homens e mulheres, ocorrendo assim um perfeito equilíbrio. Tal técnica deve ser evitada, pois, a exemplo de países como a China, em que filhos homens são mais valorizados que mulheres por questóes culturais e financeiras, geraria uma completa desordem, o que reduziria drasticamente a taxa de natalidade feminina, desencadeando um grande problema para o país. Certamente que, no Brasil, o impacto cultural sobre referida decisão não seria de tão grande monta como no mencionado caso chinês. Todavia, indubitável é que a proporção entre um sexo e outro seria igualmente afetada, o que, a longo prazo, traria enormes e variados problemas sociais e naturais.

3 Resolução CFM nº 1957/2010. 
Ademais, o dispositivo só permite a prática nos casos em que ocorra com o escopo de se evitarem doenças ligadas ao sexo, ou seja, doenças que, pelas características genéticas dos pais, só se manifestem em um ou noutro sexo. Isso possibilita, portanto, a escolha do sexo que não estará sujeito à doença, como é o caso do daltonismo, por exemplo (problema que afeta a visão), e da hemofilia (comprometedora do sistema de coagulação sanguínea): são doenças que se manifestam com mais frequência em homens do que em mulheres, por serem doenças recessivas; dessa forma, o recebimento, pelo homem, dos genes defeituosos (sejam do pai ou da mãe) já será suficiente para o desenvolvimento da doença, diferentemente do que ocorre com as mulheres, que, para desenvolverem referidas doenças, terão de receber genes defeituosos duplamente, ou seja, tanto do pai quanto da mãe, por terem dois cromossomos X. Nesse sentido, ainda não há legislação específica, e os que buscam as práticas neogênicas para tal finalidade acabam ficando sem qualquer embasamento ou proteção para a respectiva ação necessária. Logo, é importante que os representantes do povo busquem maior debate acerca da eugenia e da neogenia, para que o ordenamento jurídico as incorpore, resolvendo, dessa forma, as divergências doutrinárias que abarcam a matéria, bem como ponderando e balanceando conscientemente as vantagens e desvantagens da liberação de algumas práticas laboratoriais, e delimitando sua área de atuação.

\subsection{Deficiência do Processo Legislativo}

Antes da Resolução n. 1.957/2010 do Conselho Federal de Medicina, havia a Resolução n. 1.358/1992 acerca da reprodução assistida, logo, foram 18 anos para que houvesse alguma mudança, e não foram estas tão drásticas como se esperaria diante de um período tão longo de espera para a nova resolução, sendo as principais mudanças as contidas neste trecho:

Mudanças nas regras de reprodução assistida foram aprovadas pelo Conselho Federal de Medicina (CFM). Entre os destaques está a permissão para a realização de procedimentos com material biológico criopreservado (conservado sob condiçôes de baixíssimas temperaturas) após a morte e a possibilidade de mais pessoas se beneficiarem com as técnicas, independente do estado civil ou orientação sexual. ${ }^{4}$

4 Disponível em: <http://portal.cfm.org.br/index.php?option=com_content\&view=article\&id=2123 5:conselho-federal-estabelece-novas-normas-para-reproducao-assistida\&catid=3?n=142>. Acesso em: $1^{\circ}$ nov. 2012. 
Como é possível verificar, não foram mudanças demasiadamente substanciais ao se analisar a velocidade com que a Engenharia Genética evolui, trazendo inovaçóes que alteram e geram novas possibilidades na realização dos procedimentos laboratoriais relacionados à reprodução assistida.

No tocante às práticas neogênicas de seleção pré-implantatória dos gametas, nada se alterou, sendo ainda muito escasso seu tratamento jurídico, e há várias suposiçóes acerca do motivo pelo qual ocorre tamanha lentidão para esta evolução normativa.

Uma destas suposiçôes é feita pelos responsáveis pela elaboração do atual Código Civil, que foi concretizado no ano de 2002. Seus representantes afirmam que não havia como tratar matéria relativa ao Biodireito no dispositivo normativo, pois se trata de matéria sobremodo controversa, sobre cujos princípios náo há consenso entre os doutrinadores que mais se aprofundam nas nuances do tema, mesmo em se tratando da doutrina nacional. Além disto, as evoluçôes nesta área são constantes, fazendo com que ela sofra mutaçóes mesmo em seus preceitos basilares, tornando inviável a elaboração de leis que ao serem criadas logo poderiam entrar em desuso. Por outro lado, não parece ser o ideal que tema de tal importância fique sem ser encoberto pelo manto protetor do nosso ordenamento jurídico, responsável por gerar estabilidade nas relaçóes civis.

Em suma, seus preceitos atestam que o Direito não necessita de intervençáo humana, pois sua evolução se dá naturalmente, de tal forma que as leis seriam um empecilho para esta evoluçáo natural, tornando o Direito, que naturalmente flui, algo quase estático. Logo, se opunham à codificação do Direito, defendendo sua harmonização evolutiva de acordo com os costumes, acompanhando as transformaçóes dos demais atores sociais, a exemplo dos fatores econômicos, políticos, sociais, científicos e religiosos.

Caso tais pensamentos tenham total observância no mundo concreto, poder-se-ia associar a lentidão com que os dispositivos jurídicos têm se desenvolvido no tocante às práticas do Biodireito ao fato de que é justamente esta normatização que torna o Direito estático, privando sua evoluçáo natural, que se daria juntamente com a evolução científica no campo, possibilitando maior mobilidade entre as decisóes 
tomadas pelas autoridades designadas, que poderiam estar em constante debate, transmitindo seus pareceres à sociedade mediante o desenrolar dos fatos e avanços científicos.

Por outro lado, muitos atestam a necessidade da codificação do Direito para que haja uma verdadeira estabilidade jurídica, que propicie segurança aos cidadãos, sabendo que ninguém alterará os dispositivos normativos a seu bel-prazer, e que este processo será feito mediante amplo debate por aqueles designados para representar o povo no processo legislativo. Ainda, como afirmava Ihering em sua obra A Luta pelo Direito, a evolução do Direito não se trata simplesmente de algo natural, mas sim de uma luta, que reflete tanto no campo individual quanto no coletivo, para manutenção de seus direitos, fazendo com que os interesses da sociedade sejam realmente protegidos. Logo, não se trata de apenas esperar esta evolução, mas sim lutar por ela.

O certo é que de uma maneira ou de outra há esta deficiência no processo legislativo acerca destas práticas em questáo, havendo a necessidade de os governantes repensarem maneiras de dirimir tais mazelas.

\subsection{Bioética}

"Ética" é uma palavra que vem do grego e significa "aquilo que pertence ao caráter”. É uma área que tem como centro as questóes ditas morais estudadas pela Filosofia, e que busca condutas e preceitos bem estruturados e embasados, de forma que haja um consistente apoio para que uma melhor convivência entre os indivíduos seja propiciada na sociedade.

Todavia, importante é que se frise que, não raras vezes, existe uma relativização dos princípios éticos, o que se traduz, por exemplo, no fato de que alguns efeitos produzidos por dado preceito, em determinada sociedade, náo serão os mesmos produzidos em outra, com cultura, crenças e costumes diferentes.

No momento em que a ética afunila-se no caminho de produção de princípios que têm relação com a Biologia, tendo por intenção o estudo de quesitos ligados à vida e a sua manutenção, diz-se que se está ante a bioética. 
Ética prática dá um segundo nome à bioética! Ela tem por escopo o equilíbrio e a ponderaçáo acerca de determinados temas que abrangem a Biologia, mais especificamente no que toca à vida. Essas questóes podem ser encontradas em assuntos como a fertilização in vitro, o aborto, a clonagem, a eutanásia, os transgênicos, pesquisas com células tronco, entre outros. Estudiosos fazem esta ponderação no intento de se alcançar um consenso acerca de pontos táo controvertidos e que a todo momento se chocam. Fala-se então do que seria "eticamente" viável para se adotar como padráo de conduta dentro dos moldes da sociedade em questáo. Isso diz respeito a um árduo trabalho e envolvimento, uma vez que, muitas vezes, há divergentes opiniôes que vão em direção a caminhos totalmente opostos, e que, todavia, na maior parte das vezes, têm argumentos muito bem embasados e refletem fatos plausíveis. Dessa forma, tais divergências devem ser dirimidas, ponderando-se o melhor para uma solução equilibrada e sensata, trazendo à tona condutas que serão melhores para a sociedade e que trarão resultados mais satisfatórios, atendendo majoritariamente às necessidades e anseios daquele meio.

Um agente importante é a responsabilidade moral, que pode e deve se relacionar à bioética e ser estudada por ela. Diz respeito à responsabilidade inerente aos profissionais de determinadas áreas. Neste caso, dos médicos e enfermeiros.

É de importância essencial que haja uma conscientização por parte destes profissionais a respeito da responsabilidade que têm para com seus pacientes, principalmente alertando-os sobre os fatores relacionados e implicaçóes de determinadas práticas, especialmente as novas, que, em sua maioria, são desconhecidas de toda a população. Quando se liga isto à eugenia, tudo o que foi dito é de igual importância. Com o devido esclarecimento a respeito das divergências entre as categorias: "eugenia positiva” e "eugenia negativa”; e demonstradas não somente as aparentes benesses até mesmo da "eugenia negativa”, mas também suas mazelas, que somente são descobertas após uma análise mais apurada, então sim pode-se afirmar que houve uma adequada responsabilidade.

Em decorrência da grande influência da conduta médica é que são lançadas as resoluçôes do Conselho Federal de Medicina, na intenção de que se estabeleça um norte para o comportamento destes profissionais, a fim de que se evite a falta de interesse e perspicácia de alguns deles quando o assunto é biotecnologia, o que causaria transtornos. 
Já se trata, nos dias atuais, até mesmo de uma possível responsabilidade civil do médico, podendo ter de responder por danos. Vale citar, entretanto, que, quando o assunto tem a tônica na vida, não existem recursos que sejam capazes de restaurar e restituir plenamente os danos ocasionados. Assim sendo, é de extrema importância que avanços na área da bioética sejam alcançados, para que os médicos náo tenham problemas e contem, entáo, com maior respaldo em torno de sua conduta. E, dessa forma, isso se reflita em avanços da Engenharia Genética e, também, nas práticas da neogenia.

\section{CONCLUSÃO}

Pode-se destacar, diante do que foi exposto, a plena definição e esclarecimento acerca dos conceitos de eugenia e neogenia. As práticas de esterilização e infanticídio de seres considerados inferiores geneticamente são definidas pelo termo “eugenia”. Além disso, enquadra-se o incentivo da procriação entre indivíduos considerados modelos para o padrão positivo genético. Entrando já no âmbito da “neogenia”, pode-se concluir que esta é entendida pelas práticas de seleção gamética visando ao aperfeiçoamento genético. A "eugenia" é dividida entre duas distintas categorias: a "positiva" e a "negativa". A primeira tem por característica a seleção pré-implantatória gamética na intenção de que se obtenha características genéticas e biológicas específicas, a exemplo da cor dos olhos e do cabelo. Já a segunda trata-se da seleção gamética pré-implantatória com o fim de eliminar doenças congênitas.

Bem antes de o termo eugenia ser concebido, as práticas que a definem já eram praticadas, em Esparta, por exemplo, com a análise posterior ao nascimento do bebê. Encontrando-se possíveis deficiências, a eliminação do recém-nascido era feita, uma vez que não servia mais à sociedade por não atender às características bélicas necessárias. No decorrer dos anos, depois de Francis Galton, um cientista inglês, ter criado o termo, os Estados Unidos da América adotaram tais práticas doutrinadas pela eugenia, tendo como seus principais representantes os "tribunais biológicos”, que punham de lado o que os direitos fundamentais da dignidade humana expressavam e cometiam atrocidades, imitadas com requinte, posteriormente, pelos alemães nazistas. E é considerando tantas atrocidades como as ora mencionadas que as práticas neogênicas devem ser alvo de extremo cuidado, discussão e, por 
vezes, coibição. Espera-se assim que tais adormecidas ideias não retornem, agora sob a máscara científica; porque se assim acontecer, novas monstruosidades podem voltar a ocorrer e trazer infinitos males e consequências à sociedade.

Diante desse quadro, é preciso que aqueles que, com um amplo discernimento, percebam todos os malefícios e possíveis barbáries que podem voltar à tona por meio da aplicação eugênica e neogênica, defendam seus princípios e crenças, evitando ao máximo sua ocorrência, explicitando assim o quanto tais práticas vão contra a ideia inicial do ser humano e seus desígnios. Não só no campo espiritual, mas também no da Sociologia, há a necessidade de que os perigos da prática sejam expostos, de forma que fique claro o quanto seu exacerbado uso pode trazer de instabilidade social e de discriminação genética. Por fim, são indubitáveis as grandes vantagens possibilitadas pelos avanços biotecnológicos, entretanto é de extrema necessidade que a possibilidade de seu uso seja equilibrada e ponderada, e, principalmente, controlada, a fim de que se averiguem os riscos em pauta, os quais, se ignorados, podem desestabilizar toda a raça humana. Assim sendo, debates e avaliaçôes de prós e contras a respeito do assunto devem ser estimulados; a informação é sempre a melhor opção para minimizar erros. Finalmente, um ponto de segurança e equilíbrio entre a ciência, a vida, o bem-estar social deve ser buscado, de forma que, apesar de tantas possibilidades e mudanças, sempre o bom senso predomine.

A respeito da neogenia especificamente, depois de uma análise mais apurada, quer pelo aspecto social, quer pelo espiritual, acredita-se responsável e razoável defender que as referidas práticas devem, ao máximo, ser evitadas, seja sob qualquer categoria da atuação eugênica, já anteriormente definidas.

Naquilo que diz respeito à legislação, toma-se por conclusão que o historicismo jurídico não estava completamente equivocado quando expressava que, muitas vezes, as leis fazem estático o Direito, de forma que ele não acompanhe as inovaçóes trazidas pelas mudanças temporais e locais, especialmente aquelas que são científicas. De certo modo, neste caso, as controvérsias demasiadamente inerentes ao tema é que trazem a deficiência no processo legislativo, tornando necessária uma minuciosa análise de qualquer alteração possível. 
O único ponto não duvidoso de tudo que já foi tratado aqui é que, em toda a decisão em que se tiver como ponto principal a vida, há a necessidade de extremo cuidado e atenção, ponderando as implicaçóes de cada simples ato e buscando, incessantemente, o avanço no campo da bioética, de forma que o que é benéfico e justo para a sociedade seja sempre colocado em primeiro plano, como alvo maior. Além disso, a segurança jurídica também deve ter por finalidade buscar abranger as decisóes no ordenamento jurídico e também alertar os desastres decorrentes de impensadas decisóes.

\section{REFERÊNCIAS}

BANDEIRA, F. M. G. C.; GOMES, Y. M.; ABATH, F. G. C. Saúde pública e ética na era da medicina genômica: rastreamentos genéticos. Revista Bras. Saúde Maternidade Infantil, Recife, v. 6, n. 1, 2006.

CARDOSO, M. H. C. A.; CASTIEL, L. D. Saúde coletiva, nova genética e a eugenia de mercado. Caderno saúde pública, v. 19, n. 2, 2003.

CUÉLlAR, A. C. Raza, Alteridad y exclusión en Alemania durante la década de 1920, Revista de Estudios Sociales, n. 26, 2007.

EAGLETON, Terry. A ideia de cultura. Trad. Sandra Castello Branco. São Paulo: Unesp, 2005.

FRAGA, I. O.; AGUIAR, M. N. Neoeugenia: o limite entre a manipulação gênica e terapêutica ou reprodutiva e as práticas biotecnológicas seletivas da espécie humana. Revista Bioética, v. 18, n. 1, 2010.

FRANÇA, Genival Veloso de. Medicina Legal. Rio de Janeiro: Guanabara Koogan, 2001.

GUIMARÃES, M. A.; CARVALHO, W. L. P.; OLIVEIRA, M. S. Raciocínio moral na tomada de decisôes em relação a questôes sociocientíficas: o exemplo do melhoramento genético humano. Ciência e Educação, v. 16, n. 2, 2010.

IHERING, Rudolph Von. A luta pelo direito. São Paulo: Hunter Books, 2012.

KAHAN, Dan M. et al. Culture and Identity-Protective Cognition: Explaining the White Male Effect in Risk Perception. Journal of Empirical Legal Studies, vol. 4, n. 3, p. 465-505, nov. 2007; Yale Law School, Public Law Working Paper, n. 152. Disponível em: <http:// ssrn.com/abstract=995634>. Acesso em: 4 nov. 2015. 
LEITE, E. O. Eugenia e bioética: os limites da ciência face à dignidade humana. Revista Jurídica, v. 321, 2004.

MAI, L. D.; ANGERAMI, E. L. S. Eugenia negativa e positiva: significado e contradiçóes. Revista Latino-Am. Enfermagem, v. 14, n. 2, 2006.

OLIVEIRA, Cleberson Cardoso de. O direito à saúde aos pacientes conforme a Constituição da República de 1988. Revista Direitos Sociais e Politicas Públicas - Unifafibe. v. 3, n. 1, 2015. Disponível em: <http://www.unifafibe.com.br/revista/index.php/direitos-sociais-politicas-pub/article/view/66/pdf_35>. Acesso em: 7 jan. 2017.

OLIVEIRA, J. S.; HAMMERSCHMIDT, D. Genoma humano: eugenia e discriminação genética. Revista Jurídica Cesumar, v. 8, n. 1, 2008.

PRADO, Luiz Regis; CARVALHO, Érika Mendes de; CARVALHO, Gisele Mendes de. Curso de direito penal brasileiro. 13. ed. rev. atual. e ampl. São Paulo: Editora Revista dos Tribunais, 2014. p. 663-681.

RHODE, Deborah; PACKEL, Amanda K. Diversity on Corporate Boards: How Much Difference Does Difference Make? Delaware Journal of Corporate Law (DJCL), vol. 39, n. 2, p. 377-426, 2014. Disponível em: <http://ssrn.com/abstract=1685615>. Acesso em: 4 nov. 2015 .

SCHRAMM, F. R. Eugenia, eugenética e o espectro do eugenismo: consideraçóes atuais sobre biotecnologia e bioética. Revista Bioética, v. 5, n. 2, 2008.

SILVEIRA, E. A. cura da raça: eugenia e higienismo no discurso médico sul-rio-grandense nas primeiras décadas do século XX. Caderno Saúde Pública, Rio de Janeiro, v. 23, n. 1, 2007.

SIQUEIRA, Dirceu Pereira; CASTRO, Lorenna Roberta Barbosa. Minorias e grupos vulneráveis: a questâo terminológica como fator preponderante para uma real inclusão social. Revista Direitos Sociais e Políticas Públicas - Unifafibe, v. 5, n. 1, 2017.

SIQUEIRA, Dirceu Pereira; SAMPARO, Ana Julia Fernandes. Os direitos da mulher no mercado de trabalho: da discriminação de gênero à luta pela igualdade. Revista Direito em Debate, v. 26, n. 48, 2017.

SUNSTEIN, Cass R. Social and Economic Rights? Lessons from South Africa (May 2001). U of Chicago, Public Law Working Paper, n. 12; U Chicago Law \& Economics, Olin Working Paper n. 124. Disponível em: <http://ssrn.com/abstract=269657>. Acesso em: 4 nov. 2015. WOLF, Guilherme Eidelwein; BUFFON, Marciano. Custeio da seguridade social no Brasil: a controvérsia acerca do suposto déficit previdenciário. Revista Direitos Sociais e Politicas Públicas-Unifafibe, v. 5, n. 1, 2017. 